\title{
Examining Some Motoric Features of Under-15 Badminton Players of National Teams
}

\author{
Tarkk Sevindi \\ Correspondence: Tarık Sevindi, Faculty of Sports Science, Aksaray University, 68100, Aksaray, Turkey
}

Received: July 11, 2019

Accepted: August 7, 2019

Online Published: August 8, 2019

doi:10.11114/jets.v7i9.4382

URL: https://doi.org/10.11114/jets.v7i9.4382

\begin{abstract}
The aim of this research is to compare the motoric features of badminton players of the national teams participated in International tournament under-15, and to determine whether there is a correlation between the development level of motoric features and the results. Totally 48 players participated in the study, from 6 countries (Turkey, Azerbaijan, Bulgaria, Macedonia, Serbia, Georgia) participating in the $5^{\text {th }}$ International Rumi Child Sport Games, 24 of whom were females and 24 males. Stature, bodyweight, body mass index (BMI), flexibility, dominant and non-dominant hand grasping power, standing long jump, sit-up for 30 seconds, vertical jumping test, and anaerobic strength values of the participants were detected. It was determined that there were statistically significant differences $(p<0.05)$ between the countries in terms of dominant hand grasping power, vertical jumping, and standing long jump values of the male players; and in terms of bodyweight, BMI, dominant and non-dominant hand grasping power values of the female players. As conclusion, it was found that the motoric features of the players ranked in the International Tournament under- 15 were in better level, and it can be concluded for badminton sport that development of motoric features played an important role for success alongside with technique and tactic features.
\end{abstract}

Keywords: badminton; motoric features; under-15

\section{Introduction}

Badminton is one of the most favourite sports in the world, which can be played either for competition or for recreation within all age groups (Sucharitha, Reddy \& Madhavi 2014). Badminton is a rapidly developing sport worldwide. There are 192 member countries in the International Badminton Federation, and there are 111 million licensed players around the world (WBF, 2019; Yüksel, 2018).

In very short rallies in badminton, reaching each zone of the court and returning to the center is a very important factor. In badminton there is a well-known maxim: If the athlete's foot movement is fast, regular, rhythmic and harmonious he will be successful (Kale, 2011). In this way, the athlete can improve the strength of the muscles, the overall strength and the quickness, while stabilizing the running technique (Kale, 2011; Vicen, Del Coso, Millan, Salinero \& Abian, 2012). When the literature is examined, there were numerous researches, which revealed the characteristics of the play, stating that the longest rally times in females and males consecutively are 34.6 and 38.4 seconds (Aydoğmuş, Arslanoğlu \& Şenel, 2014), that the time of intervals between the points are 27-30 seconds (Abian, Castanedo, Feng, Sampedro \& Abian-Vicen, 2014), that the maximal speed of a shuttlecock measured as $421 \mathrm{~km} / \mathrm{h}$ and that it is the fastest ball in the world (Bankosz, Nawara \& Ociepa, 2013; Huynh, 2011). In another research, Seth (2016) indicated that badminton sport is characterized with short period, high intensity, and short intervals. Tactical perception is important for thinking very fast and doing necessary moves, while technical features gain importance in the quality of the hit and sending the shuttlecock to the aimed location. However, for applying technical and tactical choices smoothly and simply, it is important to be in the right place in the right time, which manifests the importance of and need to motoric features (Yüksel \& Aydos, 2017). Besides, the basic principle in badminton game is to respond every hit of the rival in the up front and upwards as much as possible. One of the most important prerequisites is to know the running techniques on the court particular to badminton game. In today's badminton feet moves based on running have importance rather than hit techniques skill. Although badminton is a racket sport theoretically based on hands, the development of motoric features is important depending on high level of struggle effort of the game. Accordingly, considering both the characteristics of the badminton sport and the basic principles of the game, it is evaluated that the development of the motoric features in badminton sport is important with regards to competition performance. That is why it is thought vital to determine the bio-motoric features of the international badminton players particularly in different age groups for a contribution to the field. 
This research is conducted to compare some motoric features of badminton players of the national teams under 15 , who participated in the $5^{\text {th }}$ International Rumi Child Sport Games from different countries, and to examine the effect of developed motoric features on the results of the tournament.

\section{Method}

The research was conducted on the players of the national teams under-15, from 6 countries (Turkey, Azerbaijan, Bulgaria, Macedonia, Serbia, Georgia) participating in the $5^{\text {th }}$ International Rumi Child Sport Games. Since the national teams participating in the tournament are composed of 4 female and 4 male players, total 48 players were participated in the research, 24 females and 24 males.

All the subjects participating in the research signed the informed consent (volunteer) form, and necessary permissions were taken from the organization committee and the country representatives. The measurements were taken two days before the game, and some limitations were applied regarding the recovery time, since it was before the tournament. In defining the ages of the players, the information on the identification card and passport was based on. The values of stature, body weight, flexibility, hand grasping power (dominant, non-dominant), standing long jump, sit ups for 30 secs, and vertical jumping were determined with measurements and tests, while BMIs and anaerobic power values were calculated with formulas. Before the tests warm-up sessions were applied for 15 minutes. The protocols regarding the tests and measurements are as follows.

\subsection{Tests Applied}

Stature and body weight: In determining the statures, a tape was used with $0.01 \mathrm{~m}$ degree of precision. Weight measurement was made with a digital scale having $0.01 \mathrm{~kg}$ degree of precision (Zorba \& Saygin, 2009).

Body Mass Index: Using body weights and lengths, BMI was determined using the BMI = Body weight / (Stature in meters) ${ }^{2}$ formula (Mackenzie, 2005).

Sit and reach test: It was determined on the sit and reach platform, and recorded in $\mathrm{cm}$ (Günay, Tamer \& Cicioğlu, 2013).

Hand Grasping Strength: Beginning from the right hand, the measurement was made with Jamar brand dynamometer and recorded in $\mathrm{kg}$, while the subject was on foot, arm straight with a $10-15^{\circ}$ angle from the shoulder on one side (Günay et al., 2013).

Standing Long Jump: At the end of the long jump without a run up, from standing position with two legs correlated, the distance in between the jumping line and the last point marked by the subject was measured in cm (Mackenzie, 2005).

Sit-ups for 30 sec: The soles of the feet are fully on the mat, knees bent $\left(90^{\circ}\right)$, hands are on each side and touching the neck, in a sitting position on the mat and the counts were recorded as the elbows touched the knees for 30 seconds (Zorba \& Saygın, 2009).

Vertical jumping test: It was determined with vertical jumping device (Zorba \& Saygin, 2009).

Anaerobic power test: It was determined with Lewis formula (Günay et al., 2013).

$(\mathrm{P}=\sqrt{ } 4,9 *$ Body Weight* $\sqrt{\mathrm{D}}) \mathrm{P}=$ Anaerobic Power, $\mathrm{D}=$ Vertical jumping distance $(\mathrm{m})$

\subsection{Statistical Evaluation}

SPSS 24.0 program was used in the analysis of the data obtained in the study. Arithmetic averages and standard deviations were given with descriptive statistics. Whether the parameters had statistically significant differences in between the countries, and in between which countries the differences were defined with Kruskal Wallis analysis, one of the nonparametric tests, considering the number of the participant players. Significance level was admitted as $p<0.05$. 


\section{Results}

Table 1. Average values according to the countries

\begin{tabular}{|c|c|c|c|c|c|c|c|c|}
\hline $\begin{array}{l}\frac{0}{0} \\
\frac{\pi}{\pi} \\
\frac{\pi}{\pi} \\
\frac{\pi}{\nu}\end{array}$ & 㐫 & $\mathrm{n}$ & 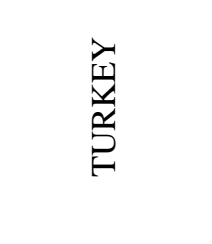 & 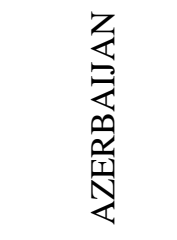 & 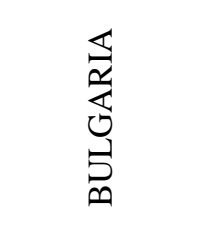 & 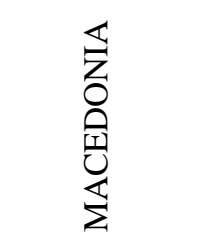 & $\frac{\nwarrow}{\sqrt{n}}$ & 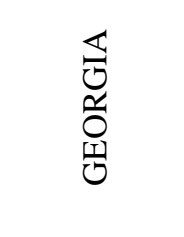 \\
\hline \multirow{2}{*}{ Age } & $\mathrm{F}$ & 4 & $14.40 \pm 0.29$ & $\begin{array}{c}14.68 \pm \\
0.22\end{array}$ & $14.58 \pm 0.26$ & $14.2 \pm 0.43$ & $14.43 \pm 0.28$ & $14.43 \pm 0.38$ \\
\hline & M & 4 & $14.50 \pm 0.22$ & $\begin{array}{l}14.33 \pm \\
0.30\end{array}$ & $14.48 \pm 0.40$ & $14.28 \pm 0.33$ & $14.43 \pm 0.30$ & $14.30 \pm 0.22$ \\
\hline \multirow{2}{*}{ Height } & $\mathrm{F}$ & 4 & $171.0 \pm 5.35$ & $\begin{array}{c}165.75 \pm \\
3.50\end{array}$ & $\begin{array}{c}165.75 \pm \\
5.97\end{array}$ & $160.0 \pm 6.38$ & $\begin{array}{c}167.25 \pm \\
7.63\end{array}$ & $\begin{array}{c}167.75 \pm \\
4.03\end{array}$ \\
\hline & $\mathrm{M}$ & 4 & $\begin{array}{c}175.25 \pm \\
2.50\end{array}$ & $\begin{array}{c}167.25 \pm \\
5.62\end{array}$ & $\begin{array}{c}167.25 \pm \\
8.85\end{array}$ & $169.0 \pm 5.48$ & $170.0 \pm 3.56$ & $\begin{array}{c}167.50 \pm \\
2.50\end{array}$ \\
\hline \multirow{2}{*}{ Weight } & $\mathrm{F}$ & 4 & $52.25 \pm 7.59$ & $\begin{array}{c}55.90 \pm \\
4.44\end{array}$ & $61.75 \pm 4.65$ & $49.63 \pm 2.06$ & $51.25 \pm 4.65$ & $54.50 \pm 3.98$ \\
\hline & M & 4 & $61.25 \pm 2.75$ & $\begin{array}{c}58.38 \pm \\
4.04\end{array}$ & $56.75 \pm 7.18$ & $63.50 \pm 5.0$ & $55.25 \pm 2.50$ & $61.33 \pm 3.62$ \\
\hline \multirow[t]{2}{*}{ BMI } & $\mathrm{F}$ & 4 & $17.81 \pm 1.93$ & $\begin{array}{c}20.33 \pm \\
1.07\end{array}$ & $22.47 \pm 1.12$ & $19.41 \pm 0.86$ & $18.35 \pm 1.72$ & $19.87 \pm 1.78$ \\
\hline & M & 4 & $19.96 \pm 1.21$ & $\begin{array}{l}20.87 \pm \\
1.16\end{array}$ & $20.23 \pm 1.11$ & $22.26 \pm 1.85$ & $19.16 \pm 1.54$ & $21.85 \pm 0.88$ \\
\hline \multirow{2}{*}{$\begin{array}{l}\text { Dominant } \\
\text { hand grasping } \\
\text { strength }\end{array}$} & $\mathrm{F}$ & 4 & $36.75 \pm 2.38$ & $\begin{array}{l}35.25 \pm \\
2.63\end{array}$ & $40.25 \pm 4.03$ & $31.75 \pm 2.22$ & $36.0 \pm 2.94$ & $36.50 \pm 1.71$ \\
\hline & $\mathrm{M}$ & 4 & $51.0 \pm 6.0$ & $\begin{array}{c}38.75 \pm \\
4.72\end{array}$ & $45.25 \pm 4.03$ & $39.0 \pm 2.58$ & $40.25 \pm 2.06$ & $35.25 \pm 2.50$ \\
\hline \multirow{2}{*}{$\begin{array}{l}\text { Non-dominant } \\
\text { hand grasping } \\
\text { strength }\end{array}$} & $\mathrm{F}$ & 4 & $31.75 \pm 0.96$ & $\begin{array}{l}29.50 \pm \\
1.73\end{array}$ & $36.25 \pm 2.06$ & $30.25 \pm 1.71$ & $34.50 \pm 2.65$ & $35.0 \pm 2.16$ \\
\hline & $\mathrm{M}$ & 4 & $44.50 \pm 6.46$ & $\begin{array}{l}39.25 \pm \\
8.06\end{array}$ & $42.25 \pm 4.03$ & $36.75 \pm 2.87$ & $38.0 \pm 1.83$ & $34.25 \pm 2.36$ \\
\hline \multirow{2}{*}{ Vertical Jump } & $\mathrm{F}$ & 4 & $42.75 \pm 2.36$ & $\begin{array}{c}32.75 \pm \\
2.99\end{array}$ & $36.0 \pm 3.65$ & $38.50 \pm 4.12$ & $44.50 \pm 5.45$ & $38.50 \pm 2.08$ \\
\hline & M & 4 & $55.50 \pm 8.18$ & $\begin{array}{l}37.25 \pm \\
8.85\end{array}$ & $\begin{array}{c}50.75 \pm \\
10.34\end{array}$ & $49.50 \pm 8.27$ & $52.50 \pm 2.65$ & $42.50 \pm 2.08$ \\
\hline \multirow{2}{*}{$\begin{array}{l}\text { Anaerobic } \\
\text { power }\end{array}$} & $\mathrm{F}$ & 4 & $\begin{array}{c}75.62 \pm \\
11.21\end{array}$ & $\begin{array}{l}70.61 \pm \\
3.58\end{array}$ & $81.92 \pm 7.33$ & $68.18 \pm 6.21$ & $75.28 \pm 3.29$ & $74.92 \pm 7.16$ \\
\hline & M & 4 & $\begin{array}{c}100.95 \pm \\
10.91\end{array}$ & $\begin{array}{l}78.53 \pm \\
11.43\end{array}$ & $\begin{array}{l}89.92 \pm \\
20.20\end{array}$ & $98.53 \pm 9.41$ & $88.64 \pm 5.54$ & $88.48 \pm 5.61$ \\
\hline \multirow{2}{*}{$\begin{array}{l}\text { Standing Long } \\
\text { Jump }\end{array}$} & $\mathrm{F}$ & 4 & $\begin{array}{c}182.25 \pm \\
7.54\end{array}$ & $\begin{array}{c}167.0 \pm \\
12.70\end{array}$ & $167.0 \pm 4.97$ & $\begin{array}{c}166.75 \pm \\
11.82\end{array}$ & $\begin{array}{c}186.75 \pm \\
12.04\end{array}$ & $\begin{array}{c}172.50 \pm \\
14.53\end{array}$ \\
\hline & M & 4 & $\begin{array}{c}231.25 \pm \\
24.86\end{array}$ & $\begin{array}{l}172.0 \pm \\
12.75\end{array}$ & $\begin{array}{l}205.0 \pm \\
24.03\end{array}$ & $\begin{array}{c}176.50 \pm \\
25.37\end{array}$ & $\begin{array}{c}206.25 \pm \\
15.44\end{array}$ & $\begin{array}{c}182.50 \pm \\
12.01\end{array}$ \\
\hline \multirow{2}{*}{ Sit and Reach } & $\mathrm{F}$ & 4 & $24.25 \pm 6.90$ & $\begin{array}{c}23.75 \pm \\
2.63\end{array}$ & $22.25 \pm 4.92$ & $30.50 \pm 5.07$ & $29.0 \pm 6.06$ & $26.50 \pm 4.44$ \\
\hline & $\mathrm{M}$ & 4 & $25.75 \pm 2.36$ & $\begin{array}{c}24.75 \pm \\
5.62\end{array}$ & $18.25 \pm 2.22$ & $28.0 \pm 2.83$ & $22.0 \pm 5.16$ & $23.63 \pm 4.94$ \\
\hline \multirow{2}{*}{$30 \mathrm{sec}$ sit-ups } & $\mathrm{F}$ & 4 & $18.25 \pm 1.71$ & $16.0 \pm 1.41$ & $14.0 \pm 3.16$ & $18.50 \pm 2.08$ & $16.50 \pm 2.38$ & $15.25 \pm 3.30$ \\
\hline & M & 4 & $27.25 \pm 2.50$ & $23.0 \pm 2.16$ & $25.25 \pm 4.11$ & $21.75 \pm 5.06$ & $24.50 \pm 3.70$ & $24.0 \pm 3.37$ \\
\hline
\end{tabular}


Table 2 . The country comparison of the female players' values

\begin{tabular}{|c|c|c|c|c|c|c|}
\hline Variables & Country & $\mathrm{n}$ & Mean Rank & $\mathrm{df}$ & $\mathrm{p}$ & dif \\
\hline & TURKEY (T) & 4 & 11.00 & & & \\
\hline & AZERBAIJAN (A) & 4 & 17.50 & & & \\
\hline \multirow[t]{8}{*}{ Age } & BULGARIA (B) & 4 & 15.13 & & & \\
\hline & MACEDONIA (M) & 4 & 7.88 & 5 & 0.468 & - \\
\hline & SERBIA (S) & 4 & 11.63 & & & \\
\hline & GEORGIA (G) & 4 & 11.88 & & & \\
\hline & Total & 24 & & & & \\
\hline & TURKEY (T) & 4 & 18.63 & & & \\
\hline & AZERBAIJAN (A) & 4 & 11.63 & & & \\
\hline & BULGARIA (B) & 4 & 12.75 & & & \\
\hline \multirow[t]{7}{*}{ Height } & MACEDONIA (M) & 4 & 6.00 & 5 & 0.245 & - \\
\hline & SERBIA (S) & 4 & 14.00 & & & \\
\hline & GEORGIA (G) & 4 & 12.00 & & & \\
\hline & Total & 24 & & & & \\
\hline & TURKEY (T) & 4 & 11.38 & & & \\
\hline & AZERBAIJAN (A) & 4 & 15.38 & & & \\
\hline & BULGARIA (B) & 4 & 20.88 & & & \\
\hline \multirow[t]{10}{*}{ Weight } & MACEDONIA (M) & 4 & 5.25 & 5 & $0.041^{*}$ & $\mathrm{M}<\mathrm{B}$ \\
\hline & SERBIA (S) & 4 & 9.00 & & & \\
\hline & GEORGIA (G) & 4 & 13.13 & & & \\
\hline & Total & 24 & & & & \\
\hline & TURKEY (T) & 4 & 6.00 & & & \\
\hline & AZERBAIJAN (A) & 4 & 14.75 & & & \\
\hline & BULGARIA (B) & 4 & 22.00 & & & \\
\hline & MACEDONIA (M) & 4 & 11.75 & 5 & $0.021^{*}$ & $\mathrm{~T}<\mathrm{B}$ \\
\hline & SERBIA (S) & 4 & 7.25 & & & $\mathrm{~S}<\mathrm{B}$ \\
\hline & GEORGIA (G) & 4 & 13.25 & & & \\
\hline \multirow[t]{5}{*}{ BMI } & Total & 24 & & & & \\
\hline & TURKEY (T) & 4 & 14.63 & & & \\
\hline & AZERBAIJAN (A) & 4 & 6.00 & & & \\
\hline & BULGARIA (B) & 4 & 20.38 & & & \\
\hline & MACEDONIA (M) & 4 & 4.75 & 5 & $0.013^{*}$ & $\mathrm{~B}>\mathrm{M}$ \\
\hline \multirow{6}{*}{$\begin{array}{l}\text { Dominant hand grasping } \\
\text { strength }\end{array}$} & SERBIA (S) & 4 & 13.88 & & & \\
\hline & GEORGIA (G) & 4 & 15.38 & & & \\
\hline & Total & 24 & & & & \\
\hline & TURKEY (T) & 4 & 10.13 & & & \\
\hline & AZERBAIJAN (A) & 4 & 5.00 & & & \\
\hline & BULGARIA (B) & 4 & 19.63 & & & \\
\hline \multirow{7}{*}{$\begin{array}{l}\text { Non-dominant } \\
\text { grasping strength }\end{array}$} & MACEDONIA (M) & 4 & 6.38 & 5 & $0.009^{*}$ & $\mathrm{~B}>\mathrm{A}$ \\
\hline & SERBIA (S) & 4 & 16.25 & & & \\
\hline & GEORGIA (G) & 4 & 17.63 & & & \\
\hline & Total & 24 & & & & \\
\hline & TURKEY (T) & 4 & 19.38 & & & \\
\hline & AZERBAIJAN (A) & 4 & 4.13 & & & \\
\hline & BULGARIA (B) & 4 & 7.88 & & & \\
\hline Vertical Jump & MACEDONIA (M) & 4 & 12.75 & 5 & $0.013^{*}$ & $\mathrm{~T}>\mathrm{A}$ \\
\hline & SERBIA (S) & 4 & 18.75 & & & $\mathrm{~S}>\mathrm{A}$ \\
\hline & GEORGIA (G) & 4 & 12.13 & & & \\
\hline & Total & 24 & & & & \\
\hline & TURKEY (T) & 4 & 14.75 & & & \\
\hline & AZERBAIJAN (A) & 4 & 8.00 & & & \\
\hline & BULGARIA (B) & 4 & 19.75 & & & \\
\hline Anaerobic power & MACEDONIA (M) & 4 & 6.50 & 5 & 0.100 & - \\
\hline & SERBIA (S) & 4 & 13.75 & & & \\
\hline & GEORGIA (G) & 4 & 12.25 & & & \\
\hline & Total & 24 & & & & \\
\hline & TURKEY (T) & 4 & 17.63 & & & \\
\hline & AZERBAIJAN (A) & 4 & 9.50 & & & \\
\hline & BULGARIA (B) & 4 & 8.75 & & & \\
\hline & MACEDONIA (M) & 4 & 8.50 & 5 & 0.116 & \\
\hline & SERBIA (S) & 4 & 19.13 & & & \\
\hline Standing Long Jump & GEORGIA (G) & 4 & 11.50 & & & \\
\hline & Total & 24 & & & & \\
\hline & TURKEY (T) & 4 & 10.25 & & & \\
\hline & AZERBAIJAN (A) & 4 & 9.13 & & & \\
\hline & BULGARIA (B) & 4 & 8.63 & & & \\
\hline & MACEDONIA (M) & 4 & 17.75 & 5 & 0.333 & \\
\hline & SERBIA (S) & 4 & 15.88 & & & \\
\hline Sit and Reach & GEORGIA (G) & 4 & 13.38 & & & \\
\hline & Total & 24 & & & & \\
\hline & TURKEY (T) & 4 & 17.63 & & & \\
\hline & AZERBAIJAN (A) & 4 & 10.50 & & & \\
\hline & BULGARIA (B) & 4 & 6.75 & & & \\
\hline & MACEDONIA (M) & 4 & 18.00 & 5 & 0.150 & \\
\hline $30 \mathrm{sec}$ sit-ups & & & & & & \\
\hline & SERBIA (S) & 4 & 12.00 & & & \\
\hline & GEORGIA (G) & 4 & 10.13 & & & \\
\hline & Total & 24 & & & & \\
\hline
\end{tabular}


When the Table 2 is examined, it was determined that there were statistically significant differences in between Bulgarian players and Macedonian players in terms of body weight; in between Bulgarian players and Turkish/Serbian players in terms of BMI; in between Bulgarian players and Macedonian players in terms of dominant hand grasping power; in between Bulgarian players and Azeri players in terms of non-dominant hand grasping power, and in between Azeri players and Turkish players in terms of vertical jumping values $(\mathrm{p}<0.05)$. There was not a statistically significant difference in between the countries in terms of age, stature, anaerobic power, standing long jump, flexibility, and sit-up for 30 seconds $(\mathrm{p}>0.05)$. 
Table 3. Country comparisons of the male players'values

\begin{tabular}{|c|c|c|c|c|c|c|}
\hline Variables & Country & $\mathrm{n}$ & Mean Rank & df & $\mathrm{p}$ & dif \\
\hline & TURKEY (T) & 4 & 15.50 & & & \\
\hline & AZERBAIJAN (A) & 4 & 11.13 & & & \\
\hline & BULGARIA (B) & 4 & 14.63 & & & \\
\hline \multirow[t]{7}{*}{ Age } & MACEDONIA (M) & 4 & 9.75 & 5 & 0.812 & - \\
\hline & SERBIA (S) & 4 & 13.50 & & & \\
\hline & GEORGIA (G) & 4 & 10.50 & & & \\
\hline & Total & 24 & & & & \\
\hline & TURKEY (T) & 4 & 20.75 & & & \\
\hline & AZERBAIJAN (A) & 4 & 9.75 & & & \\
\hline & BULGARIA (B) & 4 & 11.13 & & & \\
\hline \multirow[t]{7}{*}{ Height } & MACEDONIA (M) & 4 & 12.38 & 5 & 0.165 & - \\
\hline & SERBIA (S) & 4 & 12.88 & & & \\
\hline & GEORGIA (G) & 4 & 8.13 & & & \\
\hline & Total & 24 & & & & \\
\hline & TURKEY (T) & 4 & 15.88 & & & \\
\hline & AZERBAIJAN (A) & 4 & 11.63 & & & \\
\hline & BULGARIA (B) & 4 & 9.13 & & & \\
\hline \multirow{7}{*}{ Weight } & MACEDONIA (M) & 4 & 17.50 & 5 & 0.128 & - \\
\hline & SERBIA (S) & 4 & 5.50 & & & \\
\hline & GEORGIA (G) & 4 & 15.38 & & & \\
\hline & Total & 24 & & & & \\
\hline & TURKEY (T) & 4 & 9.50 & & & \\
\hline & AZERBAIJAN (A) & 4 & 12.75 & & & \\
\hline & BULGARIA (B) & 4 & 10.13 & & & \\
\hline \multirow[t]{6}{*}{ BMI } & MACEDONIA (M) & 4 & 18.00 & 5 & 0.056 & - \\
\hline & SERBIA (S) & 4 & 5.63 & & & \\
\hline & GEORGIA (G) & 4 & 19.00 & & & \\
\hline & Total & 24 & & & & \\
\hline & TURKEY (T) & 4 & 22.00 & & & \\
\hline & AZERBAIJAN (A) & 4 & 10.25 & & & \\
\hline \multirow{7}{*}{$\begin{array}{l}\text { Dominant hand grasping } \\
\text { strength }\end{array}$} & BULGARIA (B) & 4 & 18.25 & & & \\
\hline & MACEDONIA (M) & 4 & 9.25 & 5 & $0.004 *$ & $\mathrm{~T}>\mathrm{G}$ \\
\hline & SERBIA (S) & 4 & 11.25 & & & \\
\hline & GEORGIA (G) & 4 & 4.00 & & & \\
\hline & Total & 24 & & & & \\
\hline & TURKEY (T) & 4 & 18.63 & & & \\
\hline & AZERBAIJAN (A) & 4 & 12.25 & & & \\
\hline \multirow{8}{*}{$\begin{array}{l}\text { Non-dominant } \\
\text { grasping strength }\end{array}$} & BULGARIA (B) & 4 & 17.75 & & & \\
\hline & MACEDONIA (M) & 4 & 9.00 & 5 & 0.058 & \\
\hline & SERBIA (S) & 4 & 12.25 & & & \\
\hline & GEORGIA (G) & 4 & 5.13 & & & \\
\hline & Total & 24 & & & & \\
\hline & TURKEY (T) & 4 & 18.88 & & & \\
\hline & AZERBAIJAN (A) & 4 & 4.88 & & & \\
\hline & BULGARIA (B) & 4 & 13.88 & & & \\
\hline \multirow[t]{7}{*}{ Vertical Jump } & MACEDONIA (M) & 4 & 13.38 & 5 & $0.030^{*}$ & $\mathrm{~T}>\mathrm{A}$ \\
\hline & SERBIA (S) & 4 & 17.13 & & & $\mathrm{~S}>\mathrm{A}$ \\
\hline & GEORGIA (G) & 4 & 6.88 & & & \\
\hline & Total & 24 & & & & \\
\hline & TURKEY (T) & 4 & 18.50 & & & \\
\hline & AZERBAIJAN (A) & 4 & 6.00 & & & \\
\hline & BULGARIA (B) & 4 & 11.00 & & & \\
\hline Anaerobic power & MACEDONIA (M) & 4 & 17.00 & 5 & 0.138 & - \\
\hline & SERBIA (S) & 4 & 11.75 & & & \\
\hline & GEORGIA (G) & 4 & 10.75 & & & \\
\hline & Total & 24 & & & & \\
\hline & TURKEY (T) & 4 & 18.75 & & & \\
\hline & AZERBAIJAN (A) & 4 & 6.13 & & & \\
\hline & BULGARIA (B) & 4 & 15.75 & & & $\mathrm{~T}>\mathrm{A}$ \\
\hline & MACEDONIA (M) & 4 & 8.25 & 5 & $0.041^{*}$ & $S>A$ \\
\hline & SERBIA (S) & 4 & 17.25 & & & $\mathrm{~T}>\mathrm{M}$ \\
\hline Standing Long Jump & GEORGIA (G) & 4 & 8.88 & & & \\
\hline & Total & 24 & & & & \\
\hline & TURKEY (T) & 4 & 15.88 & & & \\
\hline & AZERBAIJAN (A) & 4 & 14.00 & & & \\
\hline & BULGARIA (B) & 4 & 4.75 & & & \\
\hline & MACEDONIA (M) & 4 & 18.75 & 5 & 0.087 & \\
\hline Sit and Reach & SERBIA (S) & 4 & 11.50 & & & \\
\hline & GEORGIA (G) & 4 & 10.13 & & & \\
\hline & Total & 24 & & & & \\
\hline & TURKEY (T) & 4 & 18.25 & & & \\
\hline & AZERBAIJAN (A) & 4 & 9.50 & & & \\
\hline & BULGARIA (B) & 4 & 14.38 & & & \\
\hline & MACEDONIA (M) & 4 & 8.38 & 5 & 0.400 & \\
\hline $30 \mathrm{sec}$ sit-ups & SERBIA (S) & 4 & 12.88 & & & \\
\hline & GEORGIA (G) & 4 & 11.63 & & & \\
\hline & Total & 24 & & & & \\
\hline
\end{tabular}


When the Table 3 is examined, it was determined that there were statistically significant differences in between Turkish players and Georgian players in terms of dominant hand grasping power; in between Azeri players and Turkish/Serbian players in terms of vertical jumping values; in between Turkish/Serbian players and Azeri players, and in between Turkish players and Macedonian players in terms of standing long jump $(\mathrm{p}<0.05)$. There was not a statistically significant difference in between the countries in terms of age, stature, anaerobic power, standing long jump, flexibility, and sit-up for 30 seconds $(\mathrm{p}>0.05)$.

\section{Discussion}

In our research, a comparison was made about some motoric features of under-15 badminton players of Turkey, Azerbaijan, Bulgaria, Macedonia, Serbia, and Georgia national teams which participated in the $5^{\text {th }}$ International Rumi Child Sport Games. Moreover, it was aimed to examine the effect of development of motoric features on the results of the tournament.

There was no statistically significant difference between the countries in terms of age average, and stature parameters of the female and male groups. Considering the height of the badminton net from the ground $(152-155 \mathrm{~cm})$, it can be stated that all of the players participated in the research were far higher than the height of the net, which did not affect the success. The fact that the height of the subject group in the research was higher than the net, was supported by numerous similar researches with regards to the higher height of the badminton players than the net (Chow, Chen \& Lin, 2016; Masu \& Nagai, 2016; Middleton, Bishop, Smith \& Gee, 2016; Vicen et al., 2012; Yüksel \& Tosun Tunç, 2018). Body weight has an important role in badminton, since it requires leaping up the body numerous times from the ground despite gravity. Accordingly, it can be stated that Bulgarian female players' values were higher than the average, which created disadvantage.

When the hand grasping power (dominant and non-dominant) of the subjects participated in the research were examined, it was determined that the best values were of Turkey and Bulgaria with regards to dominant hand grasping power in both males and females. Hand grasping power is vital for many parts of the game, particularly for the hits like drive and net-kill. When the findings obtained and the result of the tournament were evaluated together, since the Turkey and Bulgarian national teams, whose members had the highest values, were ranked as the first and the second, it can be stated that hand grasping power is crucial for the game performance. When studies in that area are examined, it was found out that the hand grasping power value of the younger age groups of Turkish national badminton players was $18.43 \mathrm{~kg}$ and amateur badminton players was $13.97 \mathrm{~kg}$ (Kafkas, Taşkıran, Arslan \& Açak, 2009); it was determined that the dominant and non-dominant hand grasping power of the Indian male badminton players (avg age:14.60) were respectively 26.43 and $24.42 \mathrm{~kg}$, while female badminton players (avg age:15.28) were respectively 20.72 and $19.63 \mathrm{~kg}$ (Koley \& Goud, 2016). It was determined that in the same age groups, for male football players it was $23.55 \mathrm{~kg}$, and for taekwondo players it was $34.93 \mathrm{~kg}$ (Menevşe, 2011). The finding that the dominant hand compared to non-dominant hand and male players compared to female players had higher hand grasping power values, was supported by similar researches (Bilgiç, Biçer \& Özdal, 2016; Çakır Atabek, 2015; Kafkas et al., 2009; Koley \& Goud, 2016). However, the values in the existing literature review are lower compared to the findings of the research conducted. This situation, for the badminton sport branch, was thought to be due to tiny age differences as mentioned in the study Kafkas et al., (2009) and because of the study groups being elite level players as mentioned in the study of Koley \& Goud (2016). Comparing to the values (Bilgiç et al., 2016; Çakır Atabek, 2015; Menevşe, 2011) obtained in other sport branches, the fact that particularly dominant hand grasping power is high, can be explained as a result of numerous exercises performed with racquets in tournaments and practices. Moreover, it can also be thought that this is because of power developing special exercises, since some technical hits (smash, drive, net-kill) in badminton sport branch necessitate tighter grasp of the racquets.

The explosive power feature of the subject participants was determined with vertical jumping test, which is one of the performance indicators. In literature review process, it was observed that there were many researches regarding jumping performance. While it was reported that vertical jumping values of 14-16 age badminton players who participated in European Badminton Team Championship were, $47.25 \mathrm{~cm}$ in Turkish badminton players, $51.50 \mathrm{~cm}$ in Hungarian badminton players, $48.75 \mathrm{~cm}$ in Belgian badminton players, and $52 \mathrm{~cm}$ in Austrian badminton players (Poyraz, Baş, Ocak, Yıldırım \& Tortop, 2015); similar vertical jumping values were observed in the badminton players who participated in Europe Young Ranking Tournament, and it was determined that there was not a statistically significant difference between countries both for male and female badminton players (Revan, Aydoğmuş, Balcı, Pepe \& Eroğlu, 2007). In another research, Ooi et al., (2009) reported that although Malaysian elite level badminton players had higher vertical jumping values compared to sub-elite level badminton players, there was not a statistically significant difference. Vertical jumping value in national basketball players under- 15 was $49 \mathrm{~cm}$ (Ayan \& Erol, 2016); while the values for female and male subjects in other sports branches were respectively $26.55 \mathrm{~cm}$ and $39.36 \mathrm{~cm}$ (Çakır Atabek, 2015); in a study conducted in Japan, it was found that the value was $42 \mathrm{~cm}$ in elite level swimmers and $50 \mathrm{~cm}$ in 
volleyball players (Yoshimura \& Umemura, 2016); it was determined $41.93 \mathrm{~cm}$ in another research conducted on Serbian students (Trajkovic, Madiç, Sporis, Veljkovic \& Zivcic-Markovic, 2016). Ghosh \& Mondal (2016), reported that badminton players have higher explosive power values compared to table tennis players. The findings of this study were observed to be higher compared to some research results (Çakır Atabek, 2015; Trajkovic et al., 2016), however, it can be mentioned that the results generally have parallels with literature review. Explosive power is important for many parts of the game in Badminton sport branch, and it can be mentioned that it is an anticipated result that the findings of the study is similar to or higher than elite level players results in literature review.

When the anaerobic power results of the badminton players were examined, no statistically significant difference was observed between countries for both male and female players. While Revan et al., (2007) reported the anaerobic power values of a group of elite level badminton players of different countries (Spain, Bulgaria, Austria, Serbia, Slovakia, Czech Republic, Croatia) in similar age groups, as 79.8 and $106.3 \mathrm{~kg}-\mathrm{m} / \mathrm{sec}$ respectively in female and male players; in another research on 14-16 age elite male badminton players, anaerobic power values were determined as 110.52 $\mathrm{kg}-\mathrm{m} / \mathrm{sec}$ in Hungarian badminton players, $99.47 \mathrm{~kg}-\mathrm{m} / \mathrm{sec}$ in Belgium badminton players, $101.61 \mathrm{~kg}-\mathrm{m} / \mathrm{sec}$ in Turkish players, and $111.56 \mathrm{~kg}-\mathrm{m} / \mathrm{sec}$ in Austrian players (Poyraz et al., 2015). In a research conducted on a higher age level 400 $\mathrm{m}$, and $400 \mathrm{~m}$ hurdle race runner athletes, while there was statistically no significant difference between two groups, it was observed that higher anaerobic power values were reached (Stolecka-Warzecha, Kaczmarczyk \& Zebrowska, 2016). In a similar study, it was observed that elite level bike racers had higher anaerobic power level compared to triathletes (Arslan \& Aras, 2016). The anaerobic power values obtained in this study were observed to be lower compared to some research results (Stolecka-Warzecha et al., 2016; Arslan \& Aras, 2016), however, it can be mentioned that the results generally have parallels with literature review. In badminton, where anaerobic energy system is predominantly used, the importance of anaerobic power was proved by the anaerobic power values of Turkish and Bulgarian national teams ranking in the first two in the tournament.

When the standing long jump values of the subjects participated in the study were examined, it was determined that male badminton players had higher values compared to females, and that there was no statistically significant difference in country comparisons of the female badminton players. The average of standing long jump values in junior age group was $241 \mathrm{~cm}$ before the 16-week-special practice and $250 \mathrm{~cm}$ after the practice (Middleton et al., 2016), and $210.63 \mathrm{~cm}$ in under-15 basketball players (Ayan \& Erol, 2016). In another research on children in Serbia (age average: 14.82), it was determined $173.62 \mathrm{~cm}$ before an 8-week-special gymnastics practice, and $186.45 \mathrm{~cm}$ after the practice (Trajkovic et al., 2016), while it was reported $158.43 \mathrm{~cm}$ and $145.12 \mathrm{~cm}$ respectively in Kosovan and Montenegrin children subjects in similar age groups who do not deal with sports (Besnik, Hazir \& Rasid, 2015). In another research conducted on 12-17 age children in India in urban and rural areas, the average standing long jump values were determined as 159.77 and $178.76 \mathrm{~cm}$ respectively (Singh, Singh \& Singh, 2016). The findings of this study are lower than the Middleton et al., (2016) study results and higher than Besnik et al., (2015) study results; however, the findings coincide with the literature review values. It can be thought that the difference was because the study group in Middleton et al., (2016) was in junior age level, and the study group in Besnik et al., (2015) was composed of individuals who did not deal with sports.

The flexibility values of the subjects participated in the study were determined with sit and reach test. When the literature of studies on similar age groups is examined, the flexibility value of male taekwondo players who had had practices for three years was $20.20 \mathrm{~cm}$, while it was $19.40 \mathrm{~cm}$ for male football players (Menevşe, 2011). In another research on male football players it was determined $17.6 \mathrm{~cm}$ (Diker \& Müniroğlu, 2016), while it was $21.90 \mathrm{~cm}$ in star male badminton players (Kafkas et al., 2009); in a research on 14-15 year old female children who had and had not dealt with sports for one year, the values were determined as 8.50 and $5.98 \mathrm{~cm}$ respectively (Bilim, Çetinkaya \& Dayı, 2016). It was evaluated that these results were lower than the finding of the study, and that it was because the subject groups of the study were international players, who accordingly had been practicing for longer periods. It was also observed that there were various different flexibility values in different sport branches and in similar age groups, and that higher values compared to this study were determined. In a study on young sportswomen group the flexibility value was determined as $28.35 \mathrm{~cm}$ (Aslan, Eyüboğlu \& Koç, 2016), and at the end of a seasonal practice program applied on 15-17 years old wrestlers it was determined as $35.61 \mathrm{~cm}$ (Cicioğlu, Kürkçü, Eroğlu \& Yüksek, 2007). These differences were evaluated to stem from practice ages, and from time periods allocated for flexibility during practices of different kinds of sports. Besides, the reason of determining many different values may be because the age group is still in puberty period, due to the orientation capacity of tendons, muscles and ligaments to the fast development of the bones.

Abdominal power and endurance of the participant subjects were determined with 30 seconds sit-up test. When the results were examined, it was determined that the male badminton players had a higher average value compared to female badminton players. This situation is supported by researches (Antunes et al., 2016; Bilim et al., 2016; Kaj, Nemeth, Tekus \& Wilhelm, 2013; Yüksel, 2017) with regards to abdominal power and endurance is higher in male 
individuals. In a study conducted on under-15 male football players 30 seconds sit-up value was 22.4 counts (Diker \& Müniroğlu, 2016); 20.08 counts in sportswomen in 14-15 age group, and 23.97 counts in males (Bilim et al., 2016); it was determined as 20.84 counts before the 12-week-special artistic gymnastics program and 26.35 counts after the program (Trajkovic et al., 2016). In a study conducted in Portugal, 30 seconds sit-up values of the subjects in 13 and 14 years old, were respectively 23.1 and 24.1 counts (Antunes et al., 2016). In another research conducted on subjects (male-female) in their adolescence periods in Hungary, Finland, and America (New York), the average value of 30 seconds sit-up was parallel with our finding regarding the male badminton players, while the average value of Hungarian female subjects, different from our findings, were quite higher than the female badminton players of our study (Kaj et al., 2013). The findings of our study generally coincide with the literature; however, it was observed that the values obtained were lower than the values obtained in some researches (Kaj et al., 2013; Trajkovic et al., 2016). This situation might be because the subject group of the study was not applied sufficient abdominal exercises in practice programs. Moreover, considering that abdominal power and endurance has an effect on balance and body stabilization particularly for badminton sport branch, and since it was understood that the Core practices were not used based on interviews made with the subjects during the study, can be explained as an indicator of this difference.

\section{Conclusions and Recommendations}

In badminton sport branch, development of tactical perception is vital with regards to doing necessary moves and development of technical features gains importance for the quality of the hit and sending the shuttlecock to the aimed location. However, in order to realize desired hits, it is important to be in the right place in the right time, which manifests the importance of the development of motoric features. In our research, a comparison was made about some motoric features of under- 15 badminton players of national teams, and it was aimed to examine the effect of development of motoric features on the results of the tournament. Turkey was ranked as the champion in the tournament

(http://www.tournamentsoftware.com/sport/tournament.aspx?id=DAEC6490-6DDF-4092-93B6-71C0549E800B). As the data regarding the motoric features were examined, the male badminton players of Turkish national team had the best values in 6 out of 7 parameters (dominant hand grasping power, non-dominant hand grasping power, vertical jumping, anaerobic power, standing long jump, $30 \mathrm{sec}$ sit-ups), and had the second best value in flexibility test. On the other hand, female badminton players of the Turkish national team had the second best values in 5 out of 7 parameters (dominant hand grasping power, vertical jumping, anaerobic power, standing long jump, $30 \mathrm{sec}$ sit-ups), and it was observed that they never had the worst value in any parameter. According to these values, it can be mentioned that the motoric features of the Turkish national team are higher compared to other countries.

As a conclusion, it can be mentioned that the development of motoric features had an effect on the results of the tournament. Conducted in a narrow scope, this study will provide an opportunity for obtaining new findings in different age groups and sports branches considering the physiological needs and psychological conditions. In addition, it is considered that, further researches, similar to this study, should be conducted on different age levels and on broader participation in order for more reliable results.

\section{References}

Abian, P., Castanedo, A., Feng, X. Q., Sampedro, J., \& Abian-Vicen, J. (2014). Notational comparison of men's singles badminton matches between Olympic Games in Beijing and London. International Journal of Performance Analysis in Sport, 14, 42-53. https://doi.org/10.1080/24748668.2014.11868701

Antunes, A. M., Maia, J. A., Gouveia, E. R., Thomis, M. A., Lefevre, J. A., Teixeira, A. Q., \& Freitas, D. L. (2016). Change, stability and prediction of gross motor co-ordination in Portuguese children, Annals of Human Biology, 43(3), 201-211. https://doi.org/10.3109/03014460.2015.1058419

Arslan, E., \& Aras, D. (2016). Comparison of body composition, heart rate variability, aerobic and anaerobic performance between competitive cyclists and triathletes. Journal Phys. Ther. Sci., 28(4), 1325-1329. https://doi.org/10.1589/jpts.28.1325

Aslan, C. S., Eyüboğlu, E., \& Koç, H. (2016). The comparison of leg strength, anaerobic power and flexibility characteristics of women according to age variable. Journal of Sports and Performance Researches, 7(2), 73-77.

Ayan, V., \& Erol, E. (2016). The study of the somato type structures and the performance characteristics of Turkey's u15 mens' national basketball team players. Kastamonu Education Journal, 24(4), 2089-2098.

Aydoğmuş, M., Arslanoğlu, E., \& Şenel, Ö. (2014). Analysis of badminton competitions in 2012 London Olympics. Turkish Journal of Sport and Exercise, 16(3), 55-60. https://doi.org/10.15314/TJSE.201439615

Badminton World Federation (2019). accessed on: 11.07.2019, https://corporate.bwfbadminton.com/about/

Bankosz, Z., Nawara H., \& Ociepa, M. (2013). Assessment of simple reaction time in badminton players. Trends in 
Sport Sciences, 1(20), 54-61.

Besnik, M., Hazir, S., \& Rasid, H. (2015). Homogeneity of applied eurofit test battery with 13-year-old pupils from Kosovo and Montenegro. Sport Science, 8(2), 19-21.

Bilgiç, M., Biçer, M., \& Özdal, M. (2016). Investigation of relation 2d:4d finger ratio and sportive performance of 11-13 aged children participated in different sports. Gaziantep University Journal of Sports Sciences, 1(1), 48-56.

Bilim, A. S., Çetinkaya, C., \& Dayı, A. (2016). Investigation of physical fitness of 12-17 years old students who engage and do not engage in sports. Journal of Sports and Performance Researches, 7(2), 53-60.

Çakır, A. H. (2015). Investigation of some pulmonary functions and bio-motoric properties in 15-17 aged group of students engaged in different sports. Inonu University Journal of Physical Education and Sport Sciences, 2(1), $1-16$.

Chow, T. H., Chen, Y. S., \& Lin, M. H. (2016). The characteristics of static plantar pressure and potential pain profiles in elite badminton players. Journal of Applied Sciences Research, 12(5), 1-7.

Cicioğlu, İ., Kürkçü, R., Eroğlu, H., \& Yüksek, S. (2007). Seasonal changes on some physical and physiological caharacteristics of wrestlers aged 15-17 years. Spormetre The Journal of Physical Education and Sport Sciences, $V(4), 151-156$. https://doi.org/10.1501/Sporm_0000000085

Diker, G., \& Müniroğlu, S. (2016). Investigation of physical features of young players who are between 8-14 according to age. Ankara University Faculty of Sport Sciences Spormetre, 14(1), 45-52. https://doi.org/10.1501/Sporm_0000000283

Ghosh, C., \& Mondal, S. (2016). Comparison of abdominal strength and explosive strength of table tennis players and badminton players in school students. IOSR Journal of Sports and Physical Education, 3(3), 27-29. https://doi.org/10.9790/6737-03032729

Günay, M., Tamer, K., \& Cicioğlu, İ. (2013). Sport Physiology and Performance Measurement. (3rd Ed.). Ankara: Gazi Publication, 464-545.

Huynh, M. (2011). Training and Evaluating Champions: A Skills Acquisition Training Tool in Badminton, School of Mathematical and Geospatial Sciences College of Science, Health and Engineering, RMIT University, Melbourne.

Kafkas, M. E., Taşkıran, C., Arslan, C., \& Açak, M. (2009). The comparison of some physical, physiologic and anthropometric parameters of junior male national and amateur badminton players. Nigde University Journal of Physical Education and Sports Science, 3(1), 13-20.

Kaj, M., Nemeth, J., Tekus, E., \& Wilhelm, M. (2013). Physique, body composition and physical fitness of finish, Hungarian and American adolescents. Exercise and Quality of Life, 5(1), 19-29. https://doi.org/10.5937/exquli1301019K

Kale, R. (2011). Badminton in Schools and Clubs. Ankara, Turkey: Nobel publications, 1-48.

Koley, S., \& Goud, S. (2016). Correlations of handgrip strength with selected anthropometric variables in Indian junior and senior badminton players. International Journal of Recent Scientific Research, 7(4), 10351-10355.

Mackenzie, B. (2005). 101 Performance Evaluation Tests. Electric Word plc. London: 96.

Masu, Y., \& Nagai, M. (2016). Characteristics of lower limb muscle activity during upper limb elevation in badminton players. Journal of Physical Therapy Science, 28(9), 2510-2514. https://doi.org/10.1589/jpts.28.2510

Menevşe, A. (2011). Comparison of some motoric characteristics of male footballers and taekwondoers. Turkish Kick Boxing Federation Journal of Sport Science, 4(1), 1309-1336.

Middleton, G., Bishop, D., Smith, C., \& Gee, T. (2016). Effectiveness of a low-frequency sports-specific resistance and plyometric training programme: the case of an elite junior badminton player. International Journal of Coaching Science, 10(2), 25-34.

Ooi, C. H., Tan, A., Ahmad, A., Kwong, K. W., Sompong, R., Mohd, G., ... Thompson, M. W. (2009). Physiological characteristics of elite and sub-elite badminton players. Journal of Sports Sciences, 27(14), 1591-1599. https://doi.org/10.1080/02640410903352907

Poyraz, A., Baş., O, Ocak, Y., Yıldırım, İ., \& Tortop, Y. (2015). The comparison of some physical and physiological parameters of the athletes having participated in the European Badminton Championship. Journal of Sports and Performance Researches, 6(2), 121-133. https://doi.org/10.17155/spd.56155

Revan, S., Aydoğmuş, M., Balc1, Ş. S., Pepe, H., \& Eroğlu, H. (2007). The evaluation of some physical and 
physiological characteristics of Turkish and foreign national badminton team players. Nigde University Journal of Physical Education and Sports Science, 1(2), 63-70.

Seth, B. (2016). Determination factors of badminton game performance. International Journal of Physical Education, Sports and Health, 3(1), 20-22.

Singh, K. M., Singh, M., \& Singh, S. (2016). Study of Physical fitness among rural and urban children from Punjab. International Journal of Physical Education, Sports and Health, 3(3), 475-478.

Stolecka-Warzecha, A., Kaczmarczyk, T., \& Zebrowska, A. (2016). Assessment of anaerobic endurance based on selected biochemical parameters in $400 \mathrm{~m} / 400 \mathrm{~m}$ hurdles male athletes. Central European Journal of Sport Sciences and Medicine, 14(2), 101-110.

Sucharitha, B. S., Reddy, A. V., \& Madhavi, K. (2014). Effectiveness of plyometric training on anaerobic power and agility in female badminton players. International Journal of Pharmaceutical Research And Bio-Science, 3(4), 754-761.

Trajkovic, N., Madiç, D., Sporis, G., Veljkovic, A., \& Zivcic-Markovic, K. (2016). Impact of gymnastics program on health related fitness in adolescent pupils. Science of Gymnastics Journal, 8(2), 157-166.

Vicen, J. A., Del Coso, J., Millan, C. G., Salinero, J. J., \& Abian, P. (2012). Analysis of dehydration and strength in elite badminton players. Plos One Journal, 7(5), 1-8. https://doi.org/10.1371/journal.pone.0037821

Yoshimura, M., \& Umemura, Y. (2016). Comparison of factors related to jump performance in volleyball players and swimmers. Official Research Journal of the American Society of Exercise Physiologists, 19(4), 53-65.

Yüksel, M. F., \& Aydos, L. (2017). The effect of shadow badminton trainings on some the motoric features of badminton players. Journal of Athletic Performance and Nutrition, 4(2), 11-28.

Yüksel, M. F. \& Tosun Tunç, G. (2018). Examining the reaction times of international level badminton players under 15. Sports, 6(1), 20. https://doi.org/10.3390/sports6010020

Yüksel, M. F. (2017). Effect of badminton education on children's physical development in summer sports school. Inonu University, Journal of Physical Education and Sport Sciences, 4(3), 68-82.

Yüksel, M. F. (2018). Examination of Hit Variety of Under-15 Female Badminton Players Depending on Their Positions on the Court. The Journal of Turkish Sport Sciences, 1(2), 89-97. https://doi.org/10.15314/tsed.364194

Zorba, E., \& Saygın, Ö. (2009). Physical Activity and Physical Fitness. (2nd Ed.). İstanbul: İnceler Publications, 205-217.

\section{Copyrights}

Copyright for this article is retained by the author(s), with first publication rights granted to the journal.

This is an open-access article distributed under the terms and conditions of the Creative Commons Attribution license which permits unrestricted use, distribution, and reproduction in any medium, provided the original work is properly cited. 